\title{
PENGARUH MEDIA SOSIAL TERHADAP KEPUTUSAN PEMBELIAN MELALUI MOTIVASI KONSUMEN PADA PRODUK FAST FASHION
}

\author{
Ratih Indriyani ${ }^{*}$, Atita Suri ${ }^{2}$ \\ ${ }^{1,2}$ Program Manajemen Bisnis, Program Studi Manajemen, Fakultas Ekonomi Dan Bisnis \\ Universitas Kristen Petra, Jl. Siwalankerto 121-131, Surabaya 60236

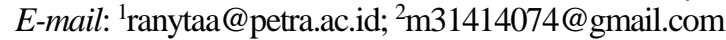 \\ *Penulis Korespondensi
}

\begin{abstract}
Abstrak: Perkembangan motivasi belanja konsumen terhadap produk fashion didukung oleh perkembangan media sosial. Di sisi lain pengambilan keputusan pembelian dalam fashion sangat dipengaruhi oleh informasi dan sumber yang tersedia di masyarakat. Penelitian ini bertujuan untuk mengetahui pengaruh dari media sosial terhadap keputusan pembelian melalui motivasi konsumen pada produk fast fashion. Penelitian ini menggunakan metode kuantitatif. Sebanyak 100 responden ditentukan dengan menggunakan purposive sampling. Data dikumpulkan menggunakan angket serta diolah menggunakan partial least square. Hasil penelitian menunjukkan bahwa media sosial berpengaruh pada keputusan pembelian, dan motivasi konsumen berpengaruh signifikan terhadap keputusan pembelian produk fast fashion.
\end{abstract}

Kata kunci: Media social; motivasi konsumen; keputusan pembelian.

\begin{abstract}
The development of cunsomer's shopping motivation towards fashion products is supported by the development of social media.On the other hand, purchasing decisions in fashion are strongly influenced by information and sources available in the community.This study aims to determine the effect of social media on purchasing decisions through consumer motivation on fast fashion products.This research uses quantitative methods.A total of 100 respondents were determined using purposive sampling.Data were collected using a questionnaire and processed using partial least square.The results showed that social media influences decisions, and consumer motivation has a significant effect on purchasing decisions for fast fashion products.
\end{abstract}

Keywords: Social media; cunsomer motivation; purchase decision

\section{PENDAHULUAN}

Dunia fashion telah berkembang dengan sangat cepat dan masyarakat pun sudah menyadari akan kebutuhan fashion yang lebih dari sekedar berpakaian, melainkan juga untuk menunjukan status sosial. Tren fashion yang terus berubah dengan cepat membuat masyarakat tidak ingin ketinggalan. Pertumbuhan industri fashiom dalam beberapa tahun terakhir dapat berkontribusi pada perubahan kebiasaan konsumen terhadap fashion. Konsumen menjadi lebih sadar mode dan menyesuaikan diri dengan tren mode terbaru (D'Aveni, 2010). Masyarakat berlomba dalam mengikuti tren yang ada dengan mencari pakaian model terbaru. Tuntutan dari masyarakat itulah yang membuat konsep fast fashion saat ini berkembang pesat. Fast fashion didefinisikan sebagai fenomena tren fashion yang berganti dengan cepat dan diproduksi secara massal berkonsep siap pakai (Dehotman, 2017). Karakteristik utama dalam fast fashion adalah harga yang terjangkau dan produk yang selalu up to date.

Banyaknya label fast fashion di Indonesia seperti H\&M, Zara, Uniqlo, Mango, Top Shop, Bershka, Cotton On, Pull and Bear, Giordano, Forever21, dan lainnya ternyata dapat memicu keinginan masyarakat dalam melakukan konsumsi produk fashion.
Pandangan masyarakat terhadap motivasi belanja produk fashion saat ini telah berubah. Hal ini didukung dengan adanya pengaruh dari media sosial. Media sosial sendiri pada perkembangannya banyak digunakan oleh perusahaan dalam industry fast fashion dalam mengembangkan usaha dan melakukan promosi (Ahmad et al, 2015).

Media sosial sekarang menjadi bagian yang tak dapat dipisahkan pada kehidupan sehari-hari banyak konsumen (Gul et al, 2014). Media sosial sangat melekat dalam komunikasi sehari-hari konsumen dan telah mengambil posisi penting dalam kehidupan masyarakat. Media sosial merupakan aktivitas dan perilaku di antara komunitas orang yang berkumpul secara online. Media sosial dapat digunakan sebagai cara berbagi pengetahuan, informasi, dan opini menggunakan aplikasi/media yang berbasis web (Jashari, 2017). Jashari dan Rrustemi (2017) menjelaskan bahwa ulasan, foto dan video dalam media sosial akan berpengaruh terhadap motivasi konsumen untuk membeli produk. $61,5 \%$ termotivasi dari ulasan teman, $51 \%$ termotivasi dari foto/video produk, $38,5 \%$ termotivasi dari comment konsumen.

Motivasi konsumen adalah keadaan di dalam diri seseorang yang mendorong keinginan untuk melakukan kegiatan guna mencapai suatu tujuan. Motivasi yang dimiliki tiap konsumen akan berpenga- 
ruh terhadap keputusan pembelian yang akan diambil. Khuong dan Duyen (2016) mengadakan penelitian mengenai motivasi yang mendorong konsumen yang memiliki karakteristik khusus. Hasil penelitian menunjukkan hasil adanya 5 faktor personal yang mempengaruhi motivasi kaum pria dalam melakukan keputusan pembelian produk skin care, di antaranya adalah kepedulian padakesehatan kulit dan daya tarik tubuh.

Media sosial akan mempengaruhi konsumen dari pencarian informasi hingga perilaku pembelian (Mangold dan Faulds, 2009). Media sosial seperti Facebook, Twitter, LinkedIn, YouTube, WhatsApp, Instagram, Tumblr, Pinterest, WeChat dan Google sangat mempermudah pengguna untuk berkomunikasi, berinteraksi, mencari informasi ataupun membagikan informasi. Kozinets (2010) meneliti bahwa media sosial semakin dipandang sebagai sumber informasi yang lebih objektif dan berpengaruh pada banyak aspek perilaku konsumen, termasuk perilaku pembelian. Khatib (2016) membuktikan bahwa pengaruh terbesar dari media sosial terjadi pada tahap pencarian informasi dan tahap keputusan pembelian. Ulasan positif pada media juga terbukti dapat mendorong terjadinya keputusan pembelian dan ulasan negatif akan menghalangi pengguna dari keputusan pembelian.

Dampak dari media sosial dapat memberi harapan yang tidak realistik dan menciptakan perasaan ketidakcukupan serta kepercayaan diri rendah bagi remaja atau kaum muda (Anna, 2017). Perasaan ketidakcukupan pada kaum muda akan memunculkan keinginan untuk menutupinya dengan cara terlihat lebih. Misalnya saja bersaing dalam hal berpakaian. Style yang sedang berkembang pada saat itu akan mendorong para remaja untuk segera mengikutinya. Motivasi mereka hanya supaya demi tercapai status sosial yang lebih tinggi dan membuat mereka lebih dihargai oleh masyarakat disekitarnya (Marwahid, 2012).

Hasil survei Brand and Marketing Institute (BMI) menunjukkan sebagian besar konsumen melakukan pembelian dengan mempertimbangkan media sosial. Data menunjukkan bahwa $80 \%$ konsumen di Indonesia sangat terpengaruh media sosial dalam menentukan produk apa yang akan dibeli (Suandy, 2017). Menurut laporan Nielsen Indonesia, konsumen Indonesia mulai menyukai belanja online seiring dengan meningkatnya penetrasi internet di Indonesia (Setiawan, 2014). Badan Pusat Statistik memaparkan 61,23\% pengguna internet di Indonesia menggunakan internet untuk mengakses media sosial (Setiawan, 2014). Dari semua media sosial, Facebook menduduki peringkat teratas dalam mempengaruhi konsumen untuk membeli produk, mencapai $44 \%$, Instagram sebesar 29\%, dan WhatsApp berperan sebanyak 8\% (Suandy, 2017). Komposisi pengguna internet di Indonesia didominasi oleh rentang usia 1934 tahun $(49,52 \%)$ pengguna berusia 13-18 tahun sebesar $16,68 \%, 29,55 \%$ pengguna berusia $35-54$ tahun dan $4,24 \%$ pengguna internet berusia 54 tahun ke atas (Setiawan, 2014).

Pada industri fast fashion, aktivitas keputusan pembelian memainkan peran yang sangat penting. Hal ini disebabkan karena fast fashion memiliki perputaran produksi dan penjualan yang sangat cepat, sehingga menyebabkan perputaran pembelian produk fast fashion juga menjadi cepat. Keputusan pembelian merupakan proses pengambilan keputusan dan aktivitas individu dalam melakukan evaluasi, mendapatkan, serta menggunakan barang dan jasa (Khuong \& Duyen, 2016).

Fashion sangat mengandalkan sosialisasi dari media sebagai bentuk komunikasi yang akan mempengaruhi keputusan pembelian. Pengambilan keputusan pembelian dalam fashion sangat dipengaruhi oleh informasi yang tersedia di masyarakat dari berbagai macam sumber seperti iklan, majalah, selebriti, teman, keluarga, dan blogger (Sudha \& Sheena, 2017). Melalui media sosial, tren fashion seakan disosialisasikan kepada masyarakat dan cenderung akan diikuti (Mega, 2017). Industri fashion akan membangun kebutuhan baru dalam masyarakat sehingga membuat masyarakat tertarik dan pada akhirnya melakukan keputusan pembelian (Sudha \& Sheena, 2017).

Berdasarkan uraian di atas, penelitian ini ingin menganalisis pengaruh penggunaan media sosial terhadap dan keputusan pembelian konsumen khususnya pada produk fast fashion. Penelitian ini ingin menganalisis motivasi konsumen sebagai variable intervening.

\section{STUDI LITERATUR}

\section{Fast Fashion}

Fast Fashion adalah istilah yang digunakan untuk mendeskripsikan koleksi pakaian yang paling banyak digunakan pada tren mode saat ini. Fast fashion didefinisikan sebagai fenomena tren fashion yang berganti dengan cepat dan diproduksi secara massal berkonsep siap pakai. Perkembangan tren yang sangat cepat didukung dengan adanya internet, kemajuan inovasi teknologi dan globalisasi (Wang, 2010). Merk fast fashion yang paling diminati masyarakat Indonesia adalah Zara, H\&M, Uniqlo, Nevada, dan Polo (Ahmad, 2018) Data dari Chainstoreage (Mccoy, 2017) membuktikan bahwa merk H\&M, Zara, Uniqlo, Forever 21, dan Mango adalah top fast fashion brand in United States yang mempunyai platform media sosial tertinggi. 


\section{Motivasi Konsumen}

Motivasi konsumen dalam berbelanja dibedakan menjadi motivasi karena kebutuhan dan motivasi pembelian untuk memenuhi kesenangan pribadi (Wagner \& Rudolph, 2010). Motivasi pembelian yang dilakukan oleh konsumen dilihat dari tujuan yang hendak dicapai, aktivitas yang dilakukan dalam berbelanja, dan motivasi yang dimiliki. Dua faktor di dalam motivasi belanja adalah adalah keinginan untuk menikmati pengalaman berbelanja dan kebutuhan keseluruhan untuk mencapai kebutuhan melalui aktivitas belanja Demand specific motivation merupakan motivasi terkait dengan fasilitas tempat belanja. Karakteristik yang diinginkan tersebut dapat berhubungan dengan berbagai aspek terkait dengan fasilitas toko, macam produk, dan personel. (Wagner dan Rudolf, 2010)

Menurut Santoso dan Purwanti (2013) dalam mengukur motivasi konsumen dalam berbelanja menggunakan pengukuran berikut ini:

1. Terdapatnya kebutuhan konsumen yang dapat dipenuhi oleh penjual.

2. Konsumen ingin membeli produk karena produk dapat meningkatkan penampilan

3. Konsumen ingin membeli karena penjual memberikan penawaran yang menarik

\section{Media Sosial}

Media sosial merupakan bentuk media yang berisi sumber-sumber online yang dihasilkan, dieksplorasi, dimanfaatkan dan disebarkan dengan maksud untuk mengedukasi orang lain tentang produk, layanan, merk, topik, dan peristiwa menarik lainnya (Rehmood \& Khan, 2011). Media sosial adalah sekelompok aplikasi berbasis internet yang dibangun berdasarkan ideologi dan fondasi teknologi web 2.0 yang memungkinkan penciptaan dan pertukaran yang dihasilkan pengguna konten (Kaplan \& Haenlein, 2010). Media sosial mengacu pada aktivitas, praktik, dan perilaku di antara komunitas orang yang berkumpul secara online untuk berbagi informasi, pengetahuan, dan opini menggunakan media percakapan (aplikasi berbasis web) (Jashari, 2017). Media sosial telah mengubah cara berkomunikasi dan cara berbagi informasi serta minat. Sekitar $75 \%$ orang telah menggunakan media sosial untuk mencari informasi sebelum melakukan pembelian. Hal ini menunjukan pertumbuhan popularitas media sosial sebagai alat informasi (Yogesh \& Yesha, 2014).

Media sosial memiliki beberapa indikator, yaitu (Khatib, 2016):

1. Adanya konten yang menarik dan menghibur
2. Adanya interaksi antara konsumen dengan penjual

3. Adanya interaksi antara konsumen dengan konsumen lain

4. Kemudahan untuk pencarian informasi produk

5. Kemudahan untuk mengkomunikasikan informasi pada publik

6. Tingkat kepercayaan pada media sosial

\section{Keputusan Pembelian}

Keputusan pembelian adalah proses pengambilan keputusan dan aktivitas fisik yang dilakukan individu ketika mengevaluasi, memperoleh, menggunakan atau membuang barang dan jasa (Khuong \& Duyen, 2016). Keputusan pembelian konsumen dalam fashion dipengaruhi oleh informasi yang tersedia di masyarakat dari berbagai macam sumber seperti iklan, majalah, selebriti, teman, keluarga, dan blogger (Sudha \& Sheena 2017). Konsumen selalu menghadapi pilihan untuk membatalkan proses atau menunda keputusan membeli. Hal ini dikarenakan banyak faktor, termasuk motivasi dan keadaan yang berubah, informasi baru yang diterima ataupun kurangnya produk yang tersedia. Dalam proses keputusan pembelian konsumen harus mempertimbangkan beberapa hal (Blackwell et al., 2012). Pertimbangan ini mencakup apakah akan membeli, kapan akan membeli, tipe dan produk yang akan dibeli, dimana akan membeli, dan bagaimana cara membayar.

Penelitian ini menggunakan indikator dalam mengukur keputusan pembelian yang disusun Ilmaya dan Hidayati (2011) sebagai berikut:

1. Kebiasaan dalam membeli produk

2. Keinginan untuk membeli produk

3. Prioritas dalam pembelian suatu produk tertentu

4. Kesediaan untuk berkorban dalam mendapatkan suatu produk

5. Pembelian produk berdasarkan manfaat produk dan harapan

\section{Hubungan Antar Konsep}

\section{Hubungan Media Sosial dan Motivasi Konsumen}

Beberapa penelitian terdahulu meneliti mengenai pengaruh media sosial terhadap motivasi konsumen dalam melakukan pembelian. Penelitian yang dilakukan oleh Jashari dan Rrustemi (2017) menunjukan bahwa ulasan, foto dan video dalam media sosial akan berpengaruh terhadap motivasi konsumen untuk membeli produk, $61,5 \%$ termotivasi dari ulasan teman, $51 \%$ termotivasi dari foto/video produk, $38,5 \%$ termotivasi dari comment konsumen. Peneliti- 
an lain dilakukan oleh Cakir et al (2013) menunjukkan media sosial akan membentuk perilaku konsumen, dan akan memotivasi konsumen hingga melakukan pembelian. Hasil menunjukan bahwa iklan yang terdapat pada media sosial akan memotivasi anak muda untuk mengetahui lebih lanjut informasi tentang produk tersebut sebelum akhirnya memutuskan untuk melakukan pembelian.

$H_{l}$ : Diduga adanya pengaruh antara media sosial terhadap motivasi konsumen produk fast fashion.

\section{Hubungan Motivasi Konsumen dan Keputusan Pembelian}

Motivasi timbul karena adanya kebutuhan yang belum terpenuhi dan tujuan yang ingin dicapai. Motivasi konsumen adalah keadaan di dalam pribadi seseorang yang mendorong keinginan individu dalam bertindak untuk mencapai suatu tujuan. Motivasi yang dimiliki tiap konsumen akan berpengaruh terhadap keputusan pembelian yang akan dilakukan.

Penelitian yang dilakukan Khuong dan Duyen (2016) menunjukan bahwa faktor personal seperti kepedulian terhadap kesehatan kulit, daya tarik tubuh, usia dan penuaan, citra diri dan kognisi akan memotivasi para pria untuk menggunakan produk skin care. Motivasi tersebut akan berdampak pada keputusan pembelian, khusunya produk-produk skin care. Penelitian lain menunjukan adanya pengaruh dari merk, artis dan blogger dalam media sosial terhadap motivasi seseorang sebelum melakukan keputusan pembelian. Hasil menunjukan bahwa blog memiliki dampak signifikan terhadap bagaimana para wanita muda terpengaruh dan pada akhirnya akan melakukan pembelian (Sudha \& Shenna, 2017).

$\mathrm{H}_{2}$ : Diduga adanya pengaruh antara motivasi konsumen terhadap keputusan pembelian produk fast fashion.

\section{Hubungan Media Sosial dan Keputusan Pembeli- an}

Penelitian Yogesh dan Yesha (2014) membuktikan bahwa media sosial memainkan peran yang penting dalam mempengaruhi keputusan pembelian konsumen di Mumbai, India. Sebagian besar $(75 \%)$ masyarakat Mumbai menggunakan media sosial untuk mencari informasi sebelum memutuskan pembelian produk. Penelitian yang dilakukan oleh Gul et al (2014) memaparkan bahwa media sosial memiliki pengaruh terhadap perilaku pembelian konsumen. Lebih lajut Khatib (2016) mempaparkan pengaruh yang terbesar dari media sosial terjadi pada tahap pencarian informasi dan tahap keputusan pembelian. Penelitian lain oleh Madni (2014) menunjukan bahwa 53\% konsumen akan mencari informasi dan ulasan pada media sosial terlebih dahulu sebelum melakukan pembelian. Ulasan dan informasi dari forum, akun media sosial, dan situs web akan mempengaruhi terjadinya keputusan pembelian konsumen.

$H_{3}$ : Diduga adanya pengaruh antara media sosial terhadap keputusan pembelian produk fast fashion.

\section{KERANGKA PENELITIAN}

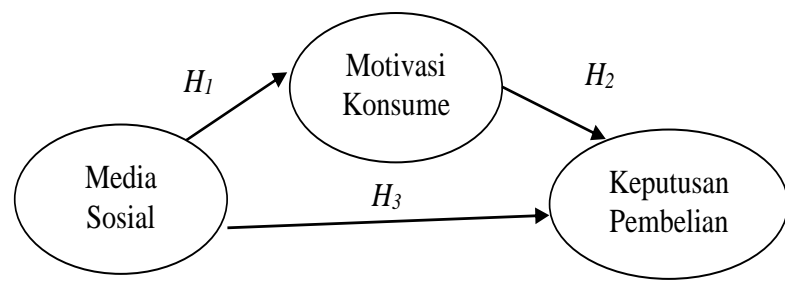

Ganbar 1. Kerangka Penelitian

\section{METODE PENELITIAN}

\section{Jenis Penelitian}

Metode yang digunakan dalam penelitian ini adalah metode kuantitatif dengan teknik penelitian explanatory. Desain penelitiannya adalah dengan data primer yang berasal dari angket tertutup. Metode pengumpulan data angket adalah dengan teknik purposive sampling.

\section{Populasi dan Sampel Penelitian}

\section{Populasi}

Populasi adalah wilayah penelitian yang hendak diambil generalisasi sehingga objek harus mempunyai kualitas dan karakteristik tertentu yang ditetapkan oleh peneliti diteliti (Sugiyono, 2016). Populasi pada penelitian ini adalah konsumen fast fashion di Surabaya.

\section{Sampel}

Menurut Sugiyono (2016), sampel adalah bagian dari jumlah populasi yang mewakili karakteristik populasi yang dituju dalam sebuah penelitian. Penentuan ukuran sampel adalah menentukan jumlah sampel yang digunakan dalam penelitian sedemikian rupa sehingga dapat mewakili populasinya. Untuk penghitungan jumlah sampel minimal, penelitian ini menggunakan rumus Slovin (Sugiyono, 2016), yaitu: 


$$
\begin{gathered}
n=\frac{Z^{2} p(1-p)}{4 e^{2}} \\
n=\frac{(1,96)^{2} 0,5(1-0,5)}{4(0,05)^{2}} \\
n=96,04 \rightarrow \text { dibulatkan menjadi } 100
\end{gathered}
$$

Dimana:

$\mathrm{n}=$ Jumlah sampel

$\mathrm{Z}=$ Angka yang menunjukkan suatu penyimpangan nilai variabel dari Mean dihitung dalam satuan deviasi standar tertentu $(1,96)$

$\mathrm{p}=$ Probabilitas $(0,5)$

$\mathrm{e}=$ Taraf kesalahan, disarankan $5 \%$

\section{Metode dan Sumber Pengumpulan Data}

Pengumpulan data dalam penelitian ini menggunakan angket. Angket merupakan teknik pengumpulan data yang dilakukan dengan memberikan pernyataan pada responden untuk dijawab sesuai kondisi secara subjektif maupun objektif yang dialami (Sugiyono, 2016). Skala pengukuran dalam penelitian menggunakan skala likert yang berhubungan pendapat dan penilaian responden. Skala likert merupakan alat ukur interval dengan lima tingkatan dalam penilaian skor dari angka 1-5. Data primer yang akan digunakan dalam penelitian ini adalah hasil dari pengisian kuesioner oleh konsumen fast fashion Surabaya. Sedangkan, Data sekunder dalam penelitian ini diperoleh melalui data teoritis yang diambil dari buku-buku dan juga jurnal pada internet.

\section{Teknik Analisis Data}

Teknik analisis data dalam penelitian ini menggunakan: analisis Partial Least Square (PLS) adalah salah satu metode statistika SEM berbasis varian yang didesain untuk menyelesaikan permasalahan spesifik pada data, seperti contoh ukuran sampel penelitian kecil, adanya data yang hilang (missing values), dan multikolinearitas.

\section{HASIL PENELITIAN DAN PEMBAHASAN}

\section{Analisis Outer Model}

\section{Convergent Validity}

PLS menggunakan uji validitas yang diukur melalui convergent validity dan discriminant validity. Convergent validity dinilai berdasarkan korelasi antar item score (component score) dengan construct score. Menurut Chin dalam Ghozali (2003), ukuran validitas dianggap memenuhi kriteria valid apabila indikator memiliki nilai loading minimal sebesar 0,7. Discriminant validitydinilai berdasarkan hasil crossloading pengukuran dengan konstruk. Jika korelasi konstruk dengan item pengukuran lebih besar daripada ukuran konstruk lainnya, maka konstruk laten memprediksi ukuran blok lebih baik daripada ukuran blok lainnya.

Hasil analisis convergent validity pada tabel 1 menunjukkan bahwa semua loading factor masingmasing variabel memiliki nilai lebih besar dari 0,7 dan nilai $t$-statistic yang lebih besar dari 1,96 (tingkat signifikansi 5\%). Hal ini menunjukkan bahwa semua indikator variabel penelitian telah memenuhi kriteria convergent validity.

Tabel 1. Hasil Uji Convergent Validity (Nilai Outer Loading)

\begin{tabular}{lcc}
\hline Variabel & Indikator & Loading Factor \\
\hline Media sosial $(X)$ & $X_{I}$ & 0,8749 \\
& $X_{2}$ & 0,8807 \\
& $X_{3}$ & 0,8922 \\
& $X_{4}$ & 0,8832 \\
Motivasi Konsumen $(Z))$ & $X_{5}$ & 0,7682 \\
& $Z_{1}$ & 0,7967 \\
& $Z_{2}$ & 0,8697 \\
Keputusan Pembelian $(Y)$ & $Z_{3}$ & 0,7746 \\
& $Y_{1}$ & 0,8358 \\
& $Y_{2}$ & 0,8429 \\
& $Y_{3}$ & 0,8188 \\
& $Y_{4}$ & 0,8543 \\
& $Y_{5}$ & 0,8283 \\
& $Y_{6}$ & 0,8507 \\
\hline
\end{tabular}

\section{Discriminant Validity}

Uji discriminant validity dilakukan dengan membandingkan akar kuadrat dari Average Variance Extracted (AVE) untuk setiap konstruk dengan korelasi antara konstruk dengan konstruk lainnya dalam model. Model penelitian dilihat mempunyai discriminant validity yang baik jika akar AVE untuk setiap konstruk lebih besar daripada korelasi antara konstruk dan konstruk lainnya dalam model.

Tabel 2. Matriks Perbandingan Akar AVE dengan Latent Variable Correlations

\begin{tabular}{llll}
\hline Variabel & $\boldsymbol{X}$ & $\boldsymbol{Y}$ & $\boldsymbol{Z}$ \\
\hline Media sosial $(X)$ & 0,861 & 0 & 0 \\
Keputusan Pembelian $(Y)$ & 0,651 & 0,839 & 0 \\
Motivasi Konsumen $(Z)$ & 0,512 & 0,768 & 0,815 \\
\hline
\end{tabular}

Tabel 2 menunjukkan bahwa akar AVE konstruk media sosial $(X)$ sebesar 0,861 lebih tinggi 
daripada korelasi antara konstruk media sosial $(X)$ dengan motivasi konsumen $(Z)$, dan keputusan pembelian $(Y)$. Nilai akar AVE konstruk motivasi konsumen (Z) sebesar 0,839lebih tinggi daripada korelasi antara konstruk motivasi konsumen $(Z)$ dengan media sosial $(X)$, dan keputusan pembelian (Y). Nilai akar AVE konstruk keputusan pembelian $(Y)$ sebesar 0,815 lebih tinggi daripada korelasi antara konstruk keputusan pembelian $(Y)$ dengan media sosial $(X)$, dan motivasi konsumen $(Z)$. Hal ini menunjukkan bahwa indikatorindikator masing-masing variabel telah tepat mengukur konstruk variabelnya.

Tabel 3.Cross Loadings

\begin{tabular}{cccc}
\hline Indikator & $\boldsymbol{X}$ & $\boldsymbol{Y}$ & $\boldsymbol{Z}$ \\
\hline$X 1$ & $\mathbf{0 , 8 7 4 9}$ & 0,5356 & 0,4219 \\
$X 2$ & $\mathbf{0 , 8 8 0 7}$ & 0,496 & 0,4222 \\
$X 3$ & $\mathbf{0 , 8 9 2 2}$ & 0,5366 & 0,3527 \\
$X 4$ & $\mathbf{0 , 8 8 3 2}$ & 0,5854 & 0,4228 \\
$X 5$ & $\mathbf{0 , 7 6 8 2}$ & 0,6151 & 0,5448 \\
$Y 1$ & 0,4876 & $\mathbf{0 , 8 3 5 8}$ & 0,7069 \\
$Y 2$ & 0,5742 & $\mathbf{0 , 8 4 2 9}$ & 0,675 \\
$Y 3$ & 0,5474 & $\mathbf{0 , 8 1 8 8}$ & 0,6236 \\
$Y 4$ & 0,5699 & $\mathbf{0 , 8 5 4 3}$ & 0,6265 \\
$Y 5$ & 0,508 & $\mathbf{0 , 8 2 8 3}$ & 0,5432 \\
$Y 6$ & 0,5834 & $\mathbf{0 , 8 5 0 7}$ & 0,6724 \\
$Z 1$ & 0,4535 & 0,6109 & $\mathbf{0 , 7 9 6 7}$ \\
$Z 2$ & 0,4333 & 0,6545 & $\mathbf{0 , 8 6 9 7}$ \\
$Z 3$ & 0,361 & 0,611 & $\mathbf{0 , 7 7 4 6}$ \\
\hline
\end{tabular}

Tabel 3 menunjukkan bahwa korelasi konstruk media sosial $(X)$ dengan indikatornya lebih tinggi dibandingkan dengan konstruk motivasi konsumen $(Z)$, dan keputusan pembelian $(Y)$. Hasil serupa terdapat pada motivasi konsumen (Z), dan keputusan pembelian $(Y)$. Hasil pengujian crossloading menunjukkan bahwa masing-masing konstruk laten memprediksi indikator bloknya lebih baik dibandingkan dengan indikator pada blok variabel lainnya.

Tabel 4.Hasil Analisis Composite Reliability dan Cronbach Alpha

\begin{tabular}{lll}
\hline Variabel & $\begin{array}{l}\text { Composite } \\
\text { Reliability }\end{array}$ & $\begin{array}{l}\text { Cronbach } \\
\text { Alpha }\end{array}$ \\
\hline Media sosial $(X)$ & 0,9346 & 0,9123 \\
Keputusan Pembelian $(Y)$ & 0,9343 & 0,9156 \\
Motivasi Konsumen $(Z)$ & 0,8552 & 0,7451 \\
\hline
\end{tabular}

Hasil analisis pada tabel menggambarkan bahwa nilai Composite Reliability dan Cronbach Alpha untuk masing-masing variabel media sosial $(\mathrm{X})$, motivasi konsumen $(\mathrm{Z})$, dan keputusan pembelian $(\mathrm{Y})$ memiliki nilai di atas 0,70 , sehingga dapat dinyatakan bahwa konstruk masing-masing variabel memenuhi kriteria uji reliabilitas.
Hasil analisis atas Outer Model

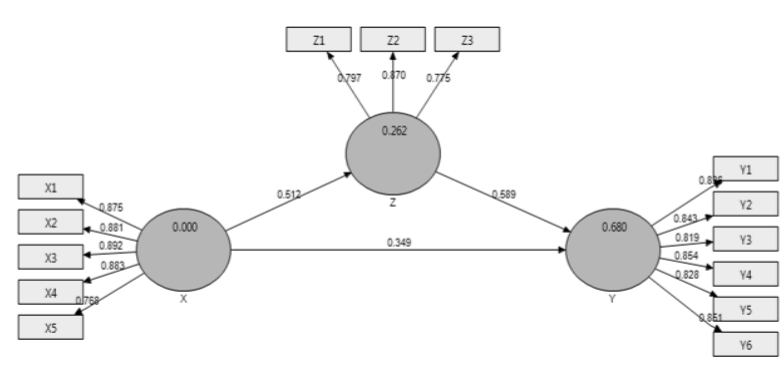

Gambar 2. Hasil Analisis Outer Model

\section{Analisis Model Struktural (Inner Model)}

\section{Uji Kolinearitas}

Sebelum melakukan penilaian hasil model struktural, harus dilakukan terlebih dahulu pengujian kolinearitas pada model struktural. Estimasi koefisien jalur (path) pada variabel latent endogen yang diprediksi oleh konstruk prediktor dalam model struktural didasarkan pada regresi OLS (Ordinary Least Squares) (Hair et al., 2014). Untuk menilai kolinearitas dapat dilihat dari nilai tolerance atau VIF. Apabila nilai tolerance dibawah 0,20 atau nilai VIF diatas 5,00 maka ada indikasi terjadinya kolinearitas. Hasil analisis atas uji kolinearitas ditunjukkan pada Tabel 5 .

Tabel 5. Pengujian Kolinearitas Pengaruh $X$ dan $Z$ Terhadap Y

\begin{tabular}{ll}
\hline Konstruk & VIF \\
\hline Media sosial $(\mathrm{X})$ & 1,355 \\
Motivasi Konsumen $(\mathrm{Z})$ & 1,355 \\
\hline
\end{tabular}

Hasil pengujian kolinearitas menunjukkan bahwa nilai VIF seluruh konstruk prediktor masih dibawah nilai batas sebesar 5,00, maka dapat disimpulkan tidak terjadi kolinearitas diantara konstruk prediktor dalam model struktural.

\section{Uji Struktural}

Pengujian signifikansi koefisien jalur dilakukan dengan membandingkan nilai $\mathrm{t}$ statistics dengan nilai $\mathrm{t}$ tabel pada tingkat signifikansi 5\%, yaitu sebesar 1,96. Koefisien jalur dianggap signifikan pengaruhnya apabila nilai $\mathrm{t}$ statistics lebih besar daripada nilai $\mathrm{t}$ tabel $(1,96)$. Hasil pengujiannya dapat dilihat pada Tabel 6.

Tabel 6. Pengujian Kolinearitas Pengaruh $X$ dan $Z$ Terhadap $Y$

\begin{tabular}{ll}
\hline Konstruk & VIF \\
\hline Media sosial $(X)$ & 1,355 \\
Motivasi Konsumen $(Z)$ & 1,355 \\
\hline
\end{tabular}


Berdasarkan hasil uji kolinearitas dapat disimpulkan tidak terjadi kolinearitas diantara konstruk prediktor dalam model structural, jika dilhat dari nilai VIF seluruh konstruk prediktor masih dibawah nilai batas sebesar 5,00.

Tabel 7. Hasil Pengujian Signifikansi Koefisien Jalur (Path) Model Struktural

\begin{tabular}{ccccc}
\hline Hubungan & $\begin{array}{c}\text { Koefisien } \\
\text { Jalur (Path) }\end{array}$ & tstatistics & $\begin{array}{c}P \\
\text { Values }\end{array}$ & Keterangan \\
\hline $\mathrm{X} \rightarrow \mathrm{Z}$ & 0,512 & 5,656 & 0,000 & Signifikan \\
$\mathrm{X} \rightarrow \mathrm{Y}$ & 0,349 & 5,936 & 0,000 & Signifikan \\
$\mathrm{Z} \rightarrow \mathrm{Y}$ & 0,589 & 10,254 & 0,000 & Signifikan \\
$\mathrm{X} \rightarrow \mathrm{Z} \rightarrow \mathrm{Y}$ & 0,302 & 5,183 & 0,000 & Signifikan \\
\hline
\end{tabular}

Berdasarkan hasil yang tertera pada tabel 7 , maka dapat dijelaskan hasil pengujian sebagai berikut:

1. Nilai koefisien jalur pada variabel media sosial (X) terhadap motivasi konsumen ( $Z$ ) adalah 0,512, dengan nilai t-statistics sebesar 5,656 > nilai t tabel sebesar 1,96 dan nilai $p$ value sebesar $0,000<$ tingkat signifikansi $(\alpha) 5 \%$ atau 0,05 . Menunjukkan bahwa media sosial $(X)$ berpengaruh signifikan positif terhadap motivasi konsumen $(Z)$.

2. Nilai koefisien jalur pada variabel media sosial (X) terhadap keputusan pembelian $(Y)$ adalah positif sebesar 0,349, dengan nilai $t$-statistics sebesar 5,936 > nilai t tabel sebesar 1,96 , dan nilai $p$ value sebesar $0,000<$ tingkat signifikansi $(\alpha) 5 \%$ atau 0,05 . Menunjukkan bahwa media sosial $(X)$ berpengaruh signifikan positif terhadap keputusan pembelian $(Y)$.

3. Nilai koefisien jalur pengaruh motivasi konsumen (Z) terhadap keputusan pembelian $(Y)$ adalah sebesar 0,589, dengan nilai t-statistics sebesar $10,254>$ nilai $t$ tabel sebesar 1,96 , dan nilai $p$ value sebesar $0,000<$ tingkat signifikansi $(\alpha) 5 \%$ atau 0,05. Hasil menunjukkan bahwa motivasi konsumen $(Z)$ berpengaruh signifikan positif terhadap keputusan pembelian (Y).

4. Nilai koefisien jalur pengaruh media sosial $(X)$ terhadap keputusan pembelian (Y) melalui motivasi konsumen $(Z)$ adalah 0,302, dengan nilai statistics sebesar 5,183> nilai $t$ tabel sebesar 1,96. Menunjukkan bahwa media sosial $(\mathrm{X})$ berpengaruh signifikan positif terhadap keputusan pembelian (Y) melalui motivasi konsumen (Z).

\section{Nilai R Square dan Stone-Geisser}

Tabel 8.Nilai Koefisien Determinasi atau $R$ Square $\left(\mathrm{R}^{2}\right)$ dan Stone-Geisser $\left(\mathrm{Q}^{2}\right)$

\begin{tabular}{lcc}
\hline Variabel Endogen & Nilai R $^{\mathbf{2}}$ & Nilai Q $^{\mathbf{2}}$ \\
\hline Motivasi Konsumen $(Z)$ & 0,262 & 0,173 \\
Keputusan Pembelian $(Y)$ & 0,680 & 0,475 \\
\hline
\end{tabular}

Hasil analisa data pada tabel 8 menjelaskan bahwa:

1. Nilai $R$ Square antara media sosial $(X)$ terhadap motivasi konsumen $(Z)$ memperlihatkan nilai sebesar 0,262. Nilai ini dapat diartikan bahwa variabilitas variabel motivasi konsumen $(Z)$ dapat dijelaskan oleh media sosial $(X)$ sebesar $26,2 \%$, sedangkan sisanya sebesar $73,8 \%$ dijelaskan oleh variabel-variabel lain yang tidak diteliti.

2. Nilai $R$ Square antara variabel $\mathrm{X}$ (media sosial) terhadap variabel $\mathrm{Z}$ (motivasi konsumen) terhadap keputusan pembelian $(Y)$ memperlihatkan nilai sebesar 0,680. Nilai tersebut mempunyai arti bahwa variabilitas keputusan pembelian $(Y)$ dapat dijelaskan oleh media sosial $(X)$ dan motivasi konsumen $(Z)$ adalah sebesar $68 \%$, sisanya sebesar $32 \%$ dijelaskan oleh variable lain yang tidak menjadi fokus penelitian.

\section{Pengujian Hipotesis}

\section{Pengujian Hipotesis Pertama}

Hipotesis pertama menyatakan bahwa diduga terdapat pengaruh antara media sosial terhadap motivasi konsumen produk fast fashion. Hasil penelitian menunjukkan bahwa koefisien jalur bernilai positif, nilai t statistik sebesar 5,656 > nilai t tabel sebesar 1,96. Hasil ini menunjukkan bahwa media sosial (X) berpengaruh signifikan positif terhadap motivasi konsumen (Z). Hipotesis pertama yang menyatakan bahwa terdapat adanya pengaruh antara media sosial terhadap motivasi konsumen produk fast fashion, diterima.

\section{Pengujian Hipotesis Kedua}

Hipotesis kedua yang ingin dianalisa adalah diduga terdapat pengaruh antara motivasi konsumen terhadap keputusan pembelian produk fast fashion. Hasil penelitian menunjukkan bahwa koefisien jalur bernilai positif dengan nilai t statistik sebesar 10,254> nilai $\mathrm{t}$ tabel sebesar 1,96. Hasil ini menunjukkan bahwa motivasi konsumen $(\mathrm{Z})$ berpengaruh positif dan signifikan terhadap keputusan pembelian (Y). Dengan demikian hipotesis kedua yang menyatakan terdapat adanya pengaruh antara motivasi konsumen terhadap keputusan pembelian produk fast fashion, diterima.

\section{Pengujian Hipotesis Ketiga}

Hipotesis ketiga dari penelitian ini adalah diduga terdapat pengaruh antara media sosial terhadap keputusan pembelian produk fast fashion. Berdasarkan data yang diperoleh terlihat bahwa koefisien jalur bernilai positif dengan nilai t statistik sebesar 5,936> nilai t tabel sebesar 1,96. Hasil ini menunjukkan bah- 
wa media sosial $(\mathrm{X})$ berpengaruh signifikan positif terhadap keputusan pembelian (Y). Hipotesis ketiga yang menyatakan bahwa diduga adanya pengaruh antara media sosial terhadap keputusan konsumen dalam membeli produk fast fashion, diterima.

\section{PEMBAHASAN}

\section{Pengaruh Media Sosial terhadap Motivasi Pem- belian}

Hasil penelitian menunjukkan bahwa media sosial berpengaruh signifikan positif terhadap motivasi konsumen dalam membeli produk fast fashion ( $t$ statistis 5,656 > 1.96). Konten yang menarik dan menghibur dalam indikator media sosial memiliki nilai rata-rata (mean) sebesar 3,81 dan termasuk pada kategori tinggi. Hasil penelitian ini sejalan dengan penelitian yang dilakukan oleh Jashari dan Rrustemi (2017). Penelitian tersebut menunjukan bahwa ulasan, foto, dan video dalam media sosial akan berpengaruh terhadap motivasi konsumen dalam membeli produk. Media sosial saat ini mengubah cara konsumen berkomunikasi dan berbagi informasi kepada rekan-rekannya. Sebagian besar konsumen menggunakan media sosial untuk mencari informasi sebelum melakukan pembelian. Ulasan di dalam media sosial dapat mendorong konsumen untuk melakukan pembelian. Konsumen yang memiliki pengalaman positif atas suatu produk dan mereka membagikan pengalamannya di media sosial akan memiliki pengaruh tinggi terhadap orang lain yang sedang mencari produk yang sama.

\section{Pengaruh Motivasi Pembelian terhadap Keputus- an Pembelian}

Motivasi konsumen untuk melakukan pembelian juga terbukti berpengaruh signifikan positif terhadap keputusan pembelian produk fastfashion ( $t$ statistis 5,936 > 1.96). Indikator motivasi konsumen yang terkait dengan kebutuhan mencari kepuasan terhadap produk memiliki nilai rata-rata (mean) tertinggi yaitu sebesar 4,13. Hasil penelitian sejalan dengan penelitian yang dilakukan oleh Khuong dan Duyen (2016). Penelitian tersebut menunjukan bahwa faktor personal seperti kepedulian terhadap kesehatan kulit, daya tarik tubuh, usia, dan penuaan, citra diri, dan kognisi akan memotivasi konsumen pria untuk menggunakan produk skin care. Semakin tinggi motivasi konsumen untuk melakukan pembelian maka akan semakin kuat keputusan pembelian yang akan dihasilkan. Motivasi pembelian merupakan pertimbangan yang mempengaruhi konsumen dalam melakukan pembelian. Motivasi pembelian konsumen dapat bersifat rasional maupun emosional. Konsumen melakukan pembelian didasarkan kepada manfaat yang diperoleh secara nyata dari sebuah produk. Konsumen rasional mendasarkan pada manfaat dari atribut produk yang fungsional serta obyektif, seperti kualitas produk, harga, ketersediaan barang, dan efisiensi kegunaan. Sedangkan konsumen yang bersifat emosional cenderung melakukan pembelian yang dikaitkan dengan hal-hal tersebut bersifat subyektif dan simbolik. Hal semacam itu mendatangkan perasaan, kesenangan karena status sosial, peranan merk karena status ekonomi sehingga konsumen memiliki motivasi dalam melakukan pembelian.

\section{Pengaruh Media Sosial terhadap Keputusan Pembelian}

Hasil penelitian menunjukkan bahwa media sosial berpengaruh signifikan positif terhadap keputusanpembelian konsumen (t-statistis 10,254 > 1.96). Indikator keputusan pembelian yang memiliki nilai ratarata tertinggi terdapat pada kesediaan untuk berkorban untuk mendapatkan suatu produk. Apabila pengaruh media sosial semakin kuat maka keputusan pembelian yang diambil konsumen untuk melakukan pembelian juga akan semakin kuat, sehingga menghasilkan pembelian yang sebenarnya. Konsumen menggunakan media sosial untuk mencari segala informasi tentang produk yang akan dibeli. Hal ini dibuktikan dengan indikator penggunaan media sosial yang terkait dengan kemudahan dalam pencarian informasi, memiliki nilai rata-rata tertinggi yaitu sebesar 3,94. Penelitian terdahulu yang dilakukan oleh Yogesh dan Yesha (2014) membuktikan hal yang serupa, yaitu adanya 75\% masyarakat Mumbai, India menggunakan media sosial untuk mencari informasi sebelum memutuskan pembelian produk. Konsumen berusaha melakukan pertimbangan dan niat dalam melakukan pembelian dengan dukungan informasi dari media sosial. Media sosial berperan besar dalam menentukan keputusan pembelian konsumen. Media sosial telah memfasilitasi dan meningkatkan aliran informasi dengan membuat kemudahan untuk menyebarkan informasi ke konsumen, sehingga konsumen dapat memiliki pertimbanganpertimbangan untuk melakukan keputusan pembelian. Konsumen saat ini juga lebih mempercayai rekomendasi dari orang-orang yang telah menggunakan produk lewat media sosial daripada penawaran langsung atau penawaran yang terdapat pada iklan. Hal tersebut dibuktikan oleh indikator media sosial yang terkait dengan tingkat kepercayaan pada media sosial memiliki nilai rata-rata tinggi sebesar 3,91. Konten yang berisi informasi akan mendapatkan respon positif dari pengguna media sosial sehingga secara cepat menyebar dan mempengaruhi konsumen. Pengaruh media sosial cenderung tinggi pada tahapan pencarian informasi dan tahap pengambilan keputusan. 


\section{KESIMPULAN}

Penelitian ini mendapatkan hasil bahwa semua variabel yang diteliti terbukti mempengaruhi variable yang lain. Penggunaan media sosial pada konsumen berpengaruh positif terhadap motivasi konsumen dalam mengkonsumsi produk fast fashion. Motivasi konsumen pada produk fast fashion memiliki pengaruh yang positif terhadap keputusan pembelian produk fast fashion. Penelitian ini juga menemukan bahwa media sosial berpengaruh positif terhadap keputusan pembelian produk fast fashion.

Media sosial saat ini banyak digunakan untuk mencari informasi bahkan hingga melakukan proses pembelian. Dengan melihat hal ini, maka perusahaan yang bergerak dalam industri fast fashion sebaiknya lebih meningkatkan konten perusahaannya seperti foto produk dan penjelasan produk agar lebih menarik dan menghibur konsumen, Penggunaan media sosial oleh konsumen sangat didasarkan pada konten yang ada, sebab konten akan mempengaruhi ketertarikan konsumen untuk lebih mengenal produk dan perusahaan. Motivasi konsumen dalam melakukan pembelian adalah hal yang penting untu dikaji, salah satunya adalah kebutuhan mencari kenyamanan pada produk. Melihat hal ini, sebaiknya perusahaan produk fast fashionlebih meningkatkan kualitas produknya yang masih terbilang rata-rata. Meningkatkan kualitas produk akan membantu mendorong konsumen untuk lebih termotivasi dalam melakukan pembelian produk tersebut. Untuk penelitian selanjutnya, dapat melakukan pengujian mengenai pengaruh antara variabel media sosial, motivasi konsumen dan keputusan pembelian pada produk lain seperti pada sektor bisnis yang lain seperti makanan dan minuman.

\section{DAFTAR PUSTAKA}

Ahmad, N, Salman, A, Ashiq, R. (2015). The Impact of Social Media on Fashion Industry: Empirical Investigation from Karachiites. Journal of Resources Development and Management, Vol 7, 1-8

Ahmad, B. R. (2018). Inilah brand-brand pilihan netizen tahun 2018. Ekbis.https://www.wartaekonomi.co.id.

Anna, K. L. (2017). Instagram, media sosial paling buruk bagi kesehatan mental. Life Style. Retrieved March 15, 2018, from http://www.kompas. co.id.

Blackwell, R. D., Miniard, P. W., Engel, F. J., Pai, D.C., Norjaya, M. Y., \& Jooria, W. H. (2012). Consumer behavior. (Yang Liping, eds). Singapore: Cengage Learning Asia Pte Ltd.
Cakir, F., Cakir, M., \& Eru, O. (2013). The effect of the social media on young consumer consumption expenditure. Internasional Journal of Social Sciences and Humanity Studies, 5(2), 86-96.

D'aveni, R. (2010). Fashion conscious: Lessons in commoditization from the fashion industry. Ivey Business Journal, 74(2), 1-4.

Dehotman, F. (2017). Ini sisi negatif pesatnya perkembangan industri fast fashion di Indonesia. Tribun Jabar. Retrieved March 15, 2018, from http://www.tribunnews.com.

Jashari, F., \& Rrustemi, V. (2017). The impact of social media on consumer behavior. Journal of Knowledge Management, Economics and Information Technology, 7(1), 1-14.

Gul, M. S., Shahzad, H, Khan, M. I. (2014) The relationship of social media with fashion consciousness and consumer buying behavior. Journal of Management Info, 1(2), 12-20

Ghozali, I. (2013). Aplikasi Analisis Multivariate dengan Program SPSS. Semarang: Universitas Diponegoro.

Hair, J.F., Hult, G.T.M., Ringle, C.M., \&Sarstedt, M. (2014). A primer on partial least squares structural equation modeling (PLS-SEM). California: SAGE Publications, Inc.

Ilmaya dan Hidayati (2011). Analisis Varian Pengaruh Interaksi Harga dan Desain Produk Terhadap Keputusan Pembelian Batik di EKA Batik Semarang. Program Sarjana Fakultas Ekonomi. Universitas Diponegoro. Semarang.

Kaplan, A. M., \& Haenlein, M. (2009). The fairyland of second life: Virtual social worlds and how to use them. Business Horizons, 52(6), 563-572

Khatib, F. (2016). The impact of social media characteristics on purchase decision empirical study of Saudi customers in Aseer Region. International Journal of Business and Social Science, 7(4), 41-50.

Khuong, M. N., \& Duyen, H. T. M. (2016). Personal factors affecting consumer purchase decision towards men skin care products - a study in Ho Chi Minh City, Vietnam International Journal of Trade, Economics and Finance, 7(2), 44-50.

Kozinets, R. (2010), The Field Behind the Screen: Using Netnography for Marketing Research in Online Communities, Journal of Marketing Research, Number 39, pp. 61-72;

Madni, G. R. (2014). Consumer's behavior and effectiveness of social media. Global Journal of Management and Business Research: E Marketing,14(8).

Mangold, W G dan Faulds, DJ (2009). Social media: The new hybrid element of the promotion mix. Business Horizons, 52, 357-365 
Marwahid, H. (2012). Hedonisme dan kaum remaja. Gaya Hidup. http://www.kompasiana.com.

Mccoy, D. (2017). Top fast fashion brand in United States. http://www.Chainstoreage.com.

Mega, A. (2017). Perkembangan trend fashion di Indonesia. Gaya Hidup. http://www.kompasiana.com.

Rehmood, R., \& Khan, M. I. (2011). The impact of eMediaon customer pruchase intention. Internation journal of Advanced computer science and application,12(1).

Setiawan, S. R. D., (2014). Ketika orang Indonesia lebih senang belanja online. Kompas Ekonomi. http://www.kompas.com.

Santoso, DT dan Purwanti, E (2013). Pengaruh Faktor Budaya, Faktor Sosial, Faktor Pribadi, Dan Faktor Psikologis Terhadap Keputusan Pembelian Konsumen dalam Memilih Produk Operator Seluler Indosat-M3 Di Kecamatan
Pringapus Kab. Semarang. Among Makarti. 6(12).

Suandy, N. (2017). Media sosial pengaruhi perilaku konsumen. Tajuk Berita Satu. http://www.beritasatu.com.

Sudha, M., Shenna, K. (2017). Impact of influencers in consumer decision process: the fashion industry. SCMS Journal of Indian Management, 14-30.

Sugiyono. (2016). Metode Penelitian Kuantitatif, Kualitatif dan R\&D. Bandung: PT Alfabeta.

Wagner, T., \& Rudolph, T. (2010). Towards a hierarchical theory of shopping motivation. Journal of Retailing and Consumer Services, 17, 415-429.

Wang, Y. T. (2010). Consumer behavior characteristics in fast fashion, 8-46.

Yogesh, F., \& Yesha, M. (2014). Effect of social media on purchase decision. Pacific Business Review International, 6(11), 45-51. 